\title{
Ownership Hierarchy and Cash Holding: A Study From Pakistan
}

\author{
Muhammad Nabeel Safdar ${ }^{1}$, Tian Lin $^{1}$, Papel Tanchangya ${ }^{1} \&$ Saba Amin ${ }^{1}$ \\ ${ }^{1}$ School of Business, Zhengzhou University, Henan, China \\ Correspondence: Muhammad Nabeel Safdar, School of Business, Zhengzhou University, Henan, China. Tel: \\ 86-183-3601-5229.
}

Received: July 15, 2019

Accepted: August 12, 2019

Online Published: August 13, 2019

doi:10.5430/ijfr.v10n6p67

URL: https://doi.org/10.5430/ijfr.v10n6p67

\begin{abstract}
This study aims to investigate the impact of the ownership hierarchy on the retention of cash. Ownership structure has dissimilar from each organization as some firms have surplus cash holdings and some firms have fewer cash holdings. This study examines the pattern of shareholding in Pakistan and its consequences on holding of cash. Trade-off theory, peaking-order theory, and agency theory have already hashed out the sensation between cash holding and ownership structure. Fixed Redundant likelihood test, Hausman Test and Panel Data Regression model are used to compute the final results. This study involves 74 non-financial firms to investigate the prime effects. The data have been taken from the biggest database of Karachi Stock Exchange (KSE) 100 index Pakistan and company financial reports from the period 2006 to 2017. Significant findings of this paper are based on two different research questions. First, how the pattern of shareholding has an impact on the decision of cash holding? Second, how the boundaries of the firm affect cash holding? These findings imply that cash holding and ownership structure are a vital element of the firm's financial policy. This paper concludes that there is a negative and substantial relationship between cash holding and the pattern of shareholdings and the boundaries of the firm have an imperative effect on the holding of cash.
\end{abstract}

Keywords: ownership structure (OS), cash holding (CH), Karachi Stock Exchange (KSE)

\section{Introduction}

With a globally integrated economic and political system, ownership hierarchy becomes a fundamental issue in the real world. It runs a vigorous part in an organization because it is equally important as the capital for the firm's and there is no mean of survival without capital. The ownership structure defined as the percentage of capital mix according to the shareholders and it has a more significant impact on firms' performance (Sun, Ding, Guo, \& Li, 2016). These capital mixes have core significance in the real business because it is the sole key to differentiate the shareholders from each other to let them know about their profitability. Globally, cash hierarchy is still a mysterious question and excess cash holding is a serious concern for the shareholders (Akhtar, 2018). As far as developing country concerns, there will be no perfect market. Therefore, in imperfect capital markets, cash retention encompasses carrying cost and opportunity cost and henceforth the magnitude of the cash holdings may affect the value of the firm (Opler, Pinkowitz, Stulz, \& Williamson, 1999). On the other hand, a firm cannot retain much capital to fulfill their short-term goals because they set up the finances from outside at zero costs immediately (Wali Ullah, Zahid, Khan, \& Islam, 2018).

In Pakistan, mostly textile firms belong to the family shareholding, and according to the world ranking Pakistan has a larger production of cotton and it also has a good exporter of cotton all over the world. Most firms in Pakistan owned by a single-family shareholding, and that is the reason which may cause the agency problem between managers and shareholders. The conflicts between managers and firm owners lead towards the agency problem. Whereas, the past studies concluded that due to the larger pattern of shareholding in the firms may cause less agency problem in an organization (Jensen \& Meckling, 1976).

Monarchy single-ownership structure is not only the problem of Pakistan. It is a problem of more than eight East-Asian Countries in which Malaysia is also on the top and where the majority of the firms are controlled and operated by the directors or the single owners. Researchers also reported that approximately $70 \%$ of the firms of East-Asian Countries top management are linked up to the family shareholdings (Claessens, Djankov, \& Lang, 2000). And according to ownership structure, the level of cash holding also affects the value of the firm because some time 
due to less holding of cash, a firm cannot avail the best opportunity. Hence, this question seeks more attention for the researchers. Should either firm hold more cash or less cash? And dose the ownership structure affects the decision of holding cash? Whereas, holding cash is an extraneous matter in the perfect capital market because firms can create a resource at negligible transaction cost (Guizani, 2017).

Nevertheless, the ambiance of an era is quite notched. Dittmar, Mahrt-Smith, and Servaes (2003) explored that global firms hold on average 9\% of the book value of their companies' assets in cash or liquid cash. Ferreira and Vilela (2004) also stated that EMU-corporations held on average 15\% of their total book value of assets in stock or cash comparable. Gao, Harford, and Li (2013) found that the public companies in the United-States of America held almost $19 \%$ of their total value of assets in cash or cash equivalent.

Therefore, by finding the research gap through empirical studies, this research paper is conducted to investigate the level of cash holding in Pakistan. However, this study will also report the impact of the shareholding pattern on cash holding with the firm size boundaries. The pattern of this paper is organized as follow: section 2 literature review, section 3 research methodology, section 4 data analysis, section-5 results, and conclusion.

\section{Literature Review}

\subsection{Cash Holding Determinants}

Notably, firm size is an essential key component concerns about holding the cash. In the past, Coase (1937) reported the firm size as a significant component for any business and also raised the question of how firm size affects the resources of allocation. Later this question had been discussed by other researchers (Grossman \& Hart, 1986; Klein, Crawford, \& Alchian, 1978; O. Williamson, 1985; O. E. Williamson, 1975). Usually, larger firms relish the economies-of-scale because they have more internal and external resources as compared to the less capital firm and they can quickly generate the funds at risk-free rate (Smith Jr \& Warner, 1979; Tayem, 2017). Furthermore, smaller firms are less diversified and have more chances of bankruptcy. Therefore, they hold more cash reserves (Titman \& Wessels, 1988). Numerous empirical studies report that smaller firms hold more cash (Bigelli \& Sánchez-Vidal, 2012; Chen, 2008; Ferreira \& Vilela, 2004; Opler et al., 1999), while many other studies report inauspicious and insignificant relationship between firm size and cash holding (García-Teruel \& Martínez-Solano, 2008; Guney, Ozkan, \& Ozkan, 2007; Aydin Ozkan \& Neslihan Ozkan, 2004).

Interestingly, Dang, Li, and Yang (2018) scrutinize more than 100 empirical papers from top journals of finance, corporate finance, economics and accounting that use firm size measures by three different proxies; (i) total assets, (ii) total sales and (iii) market value of equity. Nevertheless, they also found that these three proxies used in 85 different papers and the remaining 13 papers used multiple other techniques. Furthermore, they reported that, among these 87 research studies, 49 empirical studies used total assets as the proxy of firm size measure, 20 reviews used the market value of equity as the proxy of firm size measure, 16 studies used total sales and remaining 2 papers used number of employees. In this study, the natural log of total assets is used to measure the firm size.

A more significant number of studies reported that financial leverage and corporate cash holding have an inverse relationship with each other's (Al-Najjar \& Belghitar, 2011; Opler et al., 1999; Aydin Ozkan \& Neslihan Ozkan, 2004). Additionally, they also stated that cash holding should decrease with the increase in leverage. Because, according to the pecking order theory, if internally generated funds are inadequate, then firms will use cash reserves or go for the debt. With respect to transaction-cost-motives, highly leveraged firms hold less cash while investing in liquid asset (Ferreira \& Vilela, 2004; Kim, Mauer, \& Sherman, 1998).

Regarding the trade-off-theory, there is a negative relationship between dividend payout ratio and cash holding (Al-Najjar \& Belghitar, 2011). Empirical studies argue that dividend-paying firms can generate funds by dropping their dividend expenditures; hence they don't need to reserve a high level of cash (Drobetz \& Grüninger, 2007; Opler et al., 1999). In the Islamic state like Saudi Arabia, they believe in the "Zakat" (an Islamic-Tax) rather than a financial tax. Thus, there are no taxes on dividend payment and capital gain (Guizani, 2017).

A. Ozkan and N. Ozkan (2004) examined the adverse and substantial relationship among cash holding and free-cash-flow, whereas, pecking-order-theory reports the contradictory results. It shows a positive and significant relationship among them because higher cash flow is a likelihood of smooth and running fundamental operations with additional investment opportunities. Empirically, Saddour (2006) and Ferreira and Vilela (2004) also report the definite link between them.

Liquidity and net-working-capital both are interrelated variables and have a significant impact on the capital structure of the firm. Typically, if liquidity has a negative link with the dependent variable, then net-working-capital has a definite relation with the dependent variable and vice-versa. Opler et al. (1999) reported that there is a positive 
relationship between cash holding and liquidity. However, Al-Najjar and Clark (2017) and Ferreira and Vilela (2004) endorse this argument. On the other hand, empirical studies report that there is a negative relationship between cash holding and net-working-capital (Al-Najjar, 2013; Bates, Kahle, \& Stulz, 2009). Trade-off-theory also states the same. Whereas, Horioka and Terada-Hagiwara (2013) object the results of previous studies and later Weidemann (2018) confirm it.

\subsection{Theoretical Overview of Cash Holding}

Numerous studies have conducted on cash holding, corporate cash holding, and ownership structure, but still, the gap has not filled yet. Holding cash is typically determined and charmed by the hoard of three different theories. Trade-off theory (Myers, 1977), pecking order theory (Myers \& Majluf, 1984), free cash flow theory (Jensen, 1986).

\subsubsection{Trade-Off Theory}

Myers (1977) explained cash holding by using the trade-off theory model, which examined an optimum level of holding the cash. They also stated that an optimal level of cash holding could achieve by balancing the fringe expenses as well as fringe benefits. The firm's profit represented as marginal incentives of holding the cash, which is directly associated with cash holding firms that may neglect or reduce the financial distress in the firms. By using the instrument to execute an optimal financial investment decision and firms having a larger amount of cash holdings may decrease the level of operating cost or borrowing cost which are increased due to the external funds and by selling the tangible assets or liquidating assets.

Opler et al. (1999) stated that incremental expenses or cost of cash holding is principally the opportunity cost associated with holding cash. For example, the firm uses the holding of cash to invest in the short-term projects which are taken as transactional or preventative motives, so that's why firms hold more cash to grab the opportunities.

\subsubsection{Pecking Order Theory}

It is also known as the theory of financial hierarchy. Myers and Majluf (1984) stated that to reduce the layer of information-asymmetry and associated financial cost, firms should finance their investments from retain-earnings, debts and equity. Ferreira and Vilela (2004) reported that when a firm becomes insolvent or going to be bankrupt, then the debt issuing companies like banks have the first and foremost right to get back their money. Because while issuing the debt to the firms, there is a contract between both the parties that if in case of insolvency, then the banks have the first right on the firm's total assets. At this stage, both the parties do not hold the same degree of information that may cause the problem of asymmetric information. Hence, the determination of the Pecking order theory examined to lessening the cost of information asymmetry.

On the other hand, Opler et al. (1999) predict the contradictory theory. They reported and presented that there is an optimum level of holding the cash in the trade-off model, whereas they supported the higher level of cash holding instead of balancing the level in between the marginal profit and marginal cost. Whereas cash is a secondary element to meet the financial need in pecking order theory because business organizations use outside funds when a firm's retained earnings are not adequate to support the investment projects.

\subsubsection{Free Cash Flow Theory}

Jensen (1986) reported that cash flow theory suggests a large amount of cash holding, the controversy is that greater firms with massive cash holdings may generate more funds quickly and its fixed asset as well that ultimately increase the liquid investment of the firm. He also reported that there are two types of cash flows (i) free cash flow and (ii) operating cash flows. Operating cash flows, financing the short-term obligations or short-term investment project, whereas free cash flows are unused or available cash, after supporting all projects and meeting all functional requirements.

\subsection{Corporate Governance and Cash Holding}

Empirical studies have tried to figure out the way to observe the firms (both inside and outside) to avert the ill use of high cash holdings. Because poor corporate governance on the supplementary cash reserves results in private benefits for managers' (Akhtar, 2018; Jensen, 1986). Studies report that stronger corporate governance reduces the agency problem and enables the dividend payments to their stockholders (Opler et al., 1999). The main disadvantage of reducing the dividend outflows, it increases the cash reserves that lead to the agency cost and lessening the value of the firm (Harford, 1999), by holding the cash without no reason (Myers, 1977). GIROUD and MUELLER (2011) also confirmed the empirical results and argued that corporate governance is the backbone for the firms. 


\subsection{Significance of the Ownership Structure and Cash Holding}

To mitigate the ultimate required level of balancing the cash, Nadiri (1969) completed the first investigation to determine the holding of cash by gathering the data of 200 manufacturing companies listed on the United Stock Exchange over the period from 1948 to 1964. The empirical finding indicates that the internal and external source of information is used to examine the mandate for cash balancing. The rate of interest calculated on bank loans, the projecting rate of change in predicted values, and affecting factor prices are the internal and external sources. Campbell and Brendsel (1977) examined an experimental study by collecting the sample size of 200 manufacturing companies listed on the United Stock Exchange over the period from 1953 to 1963 in the United States. They used the Ordinary Least Squares regression (OLSR) analysis to ascertain the influence of balancing necessities on the holdings of cash, and they reported that compensation balancing cash requirements are not binding at all.

According to Opler et al. (1999), they investigated 1048 non-financial firms listed in the United Stock Exchange that publicly traded over the period from 1971 to 1993 . They used the panel data model along with the fixed-effect model and random-effect model and reported that firms with higher volatility in free cash flows and superior developing opportunities retain excess cash or cash equivalent. They too said that well-executing firms kept additional cash and it has substantial influence among holding of cash and structure of ownership. Meanwhile, Stulz (1990) examined the same results. They also observed that the stronger firms but with uncertain cash flows hold more cash to grab future opportunities. Harford, Mansi, and Maxwell (2008) and Opler et al. (1999), presented the same determinants of firm cash holding such as financial policies and agency problem with ownership structures and they found an inverse relationship among cash holding to the pattern of shareholdings.

A. Ozkan and N. Ozkan (2004) applied the sample size of 1029 non-financial firms which are publicly traded and listed on the United Kingdom Stock Exchange over the period from 1984 to 1999. They empirically inspected the determinants of cash holding and found that ownership structure has a significant influence on holding cash. They also said that there is no monotonic relation exists among managerial ownership and holding cash. Meanwhile, the other studies had conducted in Japan, where they concluded that there is a significant relationship between cash holding and ownership structure $(\mathrm{Ng}, 2005)$.

Dittmar and Mahrt-Smith (2007) reported that cash holding plays a significant role in any firm because it shows the real picture of the company performance. They also said that the worth of cash is much higher in the well-managed firms and the value of cash is much more miserable in the poorly governed firms. The factors of cash holding have discussed with the help of following theories like tradeoff theory, pecking order theory and cash flow theory and all these theories reported the different school of thoughts, but most studies reported that firms retain an optimum level of cash holdings (Myers, 1977).

Harford et al. (2008) executed different determinants of a firm's cash holdings such as solvency risk, agency problem, firm's growth and firm's financial policy. They reported that the effects of these causal factors are constant when external resources are expensive. Due to low cash flows and delivering the investment plan, firms hold liquid assets to get sure that they would accept of continuing investment. However, in short-run smaller impact has been observed on capital expenditures, acquisition spending and payouts to shareholders by excess cash.

On the other hand, Rizwan and Javed (2011) reported the tests on 300 non-financial Pakistani firms and the sample period were from 1998 to 2007 . They said that when a firm's growth and cash flow increased, then the holding of cash also increases. They also reported the negative relationship between networking capital and leverage between the corporate cash holding. Bayoumi, Tong, and Wei (2012) also explored the results with industrial cost, market frictions and political and social welfare shareholding in a private firm. There are numerous studies carried in the past, which had determined the impact of cash holding with firm size and networking capital. But no investigation was conducted in the context of ownership patterns shareholding. So, this study is conducted on the aspect of the ownership pattern shareholding through which we conclude that either these determinants have a significant impact on cash holding or not?

\section{Research Methodology}

The sample size used in this study taken from the Pakistani firms listed on the KSE (Karachi Stock Exchange Pakistan) 100 indexes. The companies have chosen based on convenience sampling because this study contains the non-financial firm's data and most firms hesitate to provide their data regarding ownership structure. In the beginning, 120 companies were taken to investigate the empirical results. Later, only 74 companies were shortlisted to get the final results due to the unavailability of ownership structure data. Mainly this study used a Panel Data model. This study computed the results of descriptive analysis, correlation matrix, common regression model, fixed effect 
likelihood model, fixed effect model, random effect model and in the end this study analyzing the Hausman test to know that either this study is going to adopt the fixed effect model or random-effect model. In the end, this study comprises the result with the help of a fixed-effect model.

\subsection{Research Equation}

The equation for this research was generated according to the variables, which is as follow;

$$
\begin{aligned}
\mathrm{CH}_{\mathrm{it}} & =\alpha+\beta_{1} \mathrm{FS}_{\mathrm{it}}+\beta_{2} \mathrm{NWC}_{\mathrm{it}}+\beta_{3} \mathrm{MBR}_{\mathrm{it}}+\beta_{4} \mathrm{LIQ}_{\mathrm{it}}+\beta_{5} \mathrm{FCF}_{\mathrm{it}}+\beta_{6} \mathrm{DIV}_{\mathrm{it}} \\
& +\beta_{7} \mathrm{LVR}_{\mathrm{it}}+\beta_{8} \mathrm{IND}_{\mathrm{it}}+\beta_{9} \mathrm{INS}_{\mathrm{it}}+\beta_{10} \mathrm{IC}_{\mathrm{it}}+\beta_{11} \mathrm{FC}_{\mathrm{it}}+\epsilon_{i t}
\end{aligned}
$$

\subsection{Research Model}

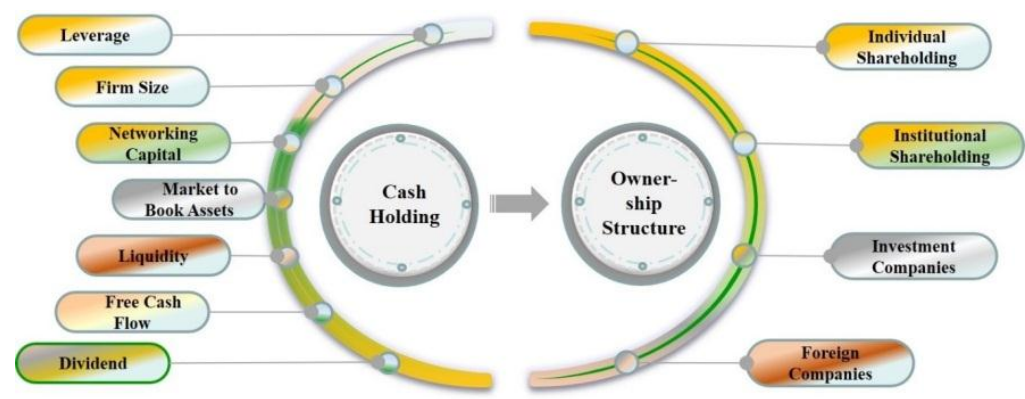

Figure 1. Research model (cash holding and ownership structure)

\subsection{Explanation of Variables}

Cash Holding $(\mathrm{CH})$ is the dependent variable of this study calculated by the total liquid cash plus total short-term securities and the total sum divided by the total asset. The same calculation adopted by Opler et al. (1999).

Firm Size (FS) variable is calculated by taking the natural log of total assets (Dang et al., 2018; Ranajee \& Pathak, 2019).

Networking Capital (NWC) is calculated by subtracting the total current liabilities from total current assets and divided by the total assets. Anake Atseye, Ugwu, and Takon (2015) and Singh and Kumar (2017) also used this formula to calculate the networking capital for their work.

Market to Book Asset Ratio (MBR) is used as a proxy to calculate the firm's growth. Market to book asset ratio calculated by market value per share divided by book value per share (Abushammala \& Sulaiman, 2014; A. Ozkan \& N. Ozkan, 2004).

Liquidity $(L I Q)$ calculated in this study by getting the value of total liquid assets divided by the total current liabilities (Ferreira \& Vilela, 2004; Opler et al., 1999; A. Ozkan \& N. Ozkan, 2004).

Leverage $(L V R)$ determined by the total liabilities of the firms divided by the total assets (A. Ozkan \& N. Ozkan, 2004).

Free Cash Flow $(F C F)$ determined in this study by computing the value from each firm's balance sheet. The data of free cash flow was taken from the balance sheet of the firms.

Dividend Payout Ratio (DIV) computed in this study by getting the dummy values. For example, the companies who are giving the dividends mark with 1 and 0 for not giving (Ranajee \& Pathak, 2019).

Ownership Variables $(\mathrm{OV})$ calculated with the help of other supporting variables like the individual pattern of shareholding, the institutional pattern of shareholding, investment companies' shareholding, foreign company's shareholding. All of these variables calculated by getting the values from the respective companies' annual balance sheets.

\section{Data Analysis}

This study contains the Panel data regression model, and firstly it computes the descriptive statistical analysis and correlation, regression model to check the relation between the variables. After that, computed the common coefficient model, which stated that the intercept and the cross-section have no distinction with each other. In other 
words, we can say that the assumption of this model is that the data is homogenous, and the equation of this model is as follows:

$$
\mathrm{Y}_{\mathrm{it}}=\beta_{\mathrm{o}}+\beta_{1} \mathrm{X}_{\mathrm{it}}+\ldots \ldots+\mu_{\mathrm{it}}
$$

After that, according to the panel data techniques, this study determined the fixed effect redundant likelihood model which is used to know that either, which model is going to choose in the common coefficient regression model, fixed effect model or random-effect model.

Table 1. Fixed redundant likelihood model

\begin{tabular}{llll}
\hline Test Model Effects & Statistic Values & D-F & Prob \\
\hline F - Cross sections & 9.768443 & $(83,603)$ & 0.0000 \\
\hline Chi Square & 521.545762 & 80 & 0.0000 \\
\hline
\end{tabular}

Table 1 rejects the null hypothesis, so the common coefficient regression model will not use to report this model anymore. Therefore, this study moves to the next step of choosing the best-fit model, either this research conducted through the random effect model or fixed-effect model. After that, the Hausman test is used to check the best fit model for this study and results shows that the fixed effect model is best for this study to accomplish the final result. The assumption of the random effect model is the same as a fixed-effect model, and the intercept is not same for all the cross-sections and time-periods. This model is used to check either intercept properly following the systematic pattern or not. And it also assumes that the beta of the function is not expressive here because it follows the random pattern. The function of the random effect model is as follow:

$$
\mathrm{Y}_{\mathrm{it}}=\left(\beta_{\mathrm{o}}+\mu\right)+\beta \mathrm{X}_{1 \mathrm{it}}
$$

Whereas the supposition of the fixed effect model is the intercept of all the cross-sections are not same for all the cross-sections. But the coefficient of a slope can be fixed across all the firms. The function of this model is as follows:

$$
\mathrm{Y}_{\mathrm{it}}=\beta_{\mathrm{it}}+\beta_{1} \mathrm{X}_{\mathrm{it}}+\ldots \ldots \ldots+\mu_{\mathrm{it}}
$$

Equation 3 will be continued to present the final results of this study and this study illustrate the impact of ownership structure on cash holding with the help of a fixed-effect model.

Table 2. Fixed effect model of cash holding

\begin{tabular}{llllll}
\hline Variables & Coefficients & Prob. & Variables & Coefficients & Prob. \\
\hline C & 0.737169 & 0.00000 & DIV & -0.013974 & 0.08440 \\
\hline FS & -0.039448 & 0.00000 & LVR & 0.332897 & 0.00000 \\
\hline NWC & 0.489438 & 0.00000 & IND & -0.001348 & 0.00003 \\
\hline MBR & -0.001340 & 0.05583 & INS & -0.001716 & 0.01893 \\
\hline LIQ & -0.124157 & 0.00000 & IC & -0.013286 & 0.00002 \\
\hline FCF & $3.25 E-09$ & 0.02222 & FC & -0.002396 & 0.00000 \\
\hline $\mathbf{R}^{2}$ & Adj $\mathbf{R}^{\mathbf{2}}$ & F-stat & Probability Value & \\
\hline 0.762753 & 0.723133 & 19.25180 & 0.000000 & & \\
\hline
\end{tabular}

Table 2 reports the inverse relationship between cash holding and firm size, which means that the size of the firms has a significant impact on the holding of cash. This study also concludes that if firms are larger, then they will hold less cash and vice versa. Results also supported the tradeoff theory, which demonstrates that larger firms always grab the opportunity to increase the firm's growth and profitability (Abor, 2005; Guizani, 2017). In Pakistan, most firms held by the family ownership, so that's why they induce a great business diversification in their business line. Therefore, they have less capital cost (Rajan \& Zingales, 1995). Furthermore, the current study reports a positive and significant relationship between cash holding and networking capital. It means that a higher amount of networking 
capital indicates that firms have more opportunity soon, and there are no chances of bankruptcy. According to the tradeoff theory, if the firms have more networking capital, then it means the firm's growth level is high, and there is no risk to the firm regarding liquidity. The results also indicate that Pakistani firms neither so big nor so small but belongs to the medium level of firms, which holds more cash to avail the best opportunity for business growth. On the other hand, this study also reports that larger firms could manage their cash from the diversification of business (Ferreira \& Vilela, 2004; Guizani, 2017; Ranajee \& Pathak, 2019). Market to book assets ratio also shows the negative and significant relationship between cash holding and ownership structure, but it has a minor effect on cash holding because value (-0.00134) shows very less impact. Rizwan and Javed (2011) also reported the inverse relation between cash holding and market to book assets. The above table also stated the inverse relationship between liquidity and cash holding. It means that when liquidity increases, then cash holding decreases. It's because when firms have more level of liquidity stock, then they don't need to get more cash. The reason behind this scenario might be that the firms who have a weak financial power, they hold more liquidity stock to cope up with their financial distress. There is one more reason to hold a lot of liquidity that the firms are not able to generate external capital due to the higher cost of capital (Drobetz \& Grüninger, 2007). It also indicates that financially constraint firms face a higher cost to raise external capital, whereas cash holding enables these firms to avoid higher cost for raising external funds (W. Faulkender \& Wang, 2006). Many researchers have also found the inverse relationship between them (Myers \& Majluf, 1984; Opler et al., 1999; Rizwan \& Javed, 2011). The Cash holding model explains the positive and significant relationship between cash holding and free cash flow (Guizani, 2017). According to the pecking order theory, it means that when cash flow shows the positive trend in the firm's balance sheet, then cash holding will also increase, which leads towards the firm's continuous growth by attaining the opportunities from the market. Ferreira and Vilela (2004) also reported the positive relation amongst the holding of cash and operating cash flows. They say that holding of cash reduced the stress to perform well and permits to the managers to spend in profitable projects, which are best suits for their interest and not for the shareholder's interest. The study also reveals the negative and insignificant relationship between dividend payout ratio and cash holding. It means that most in the Pakistani's firms, there is no trend to give the dividend to their shareholders because most firms are belonging to the family shareholding. And this result also shows the negative relation, which means that when companies give the dividend to their shareholders, then cash holding automatically reduces their level because a dividend has paid from the cash reserves. Theories also reported the inverse relationship amongst the holding of cash and dividend payments as per Trade-off theory. Al-Najjar and Belghitar (2011) also reported that those firms which paid a dividend to their shareholders are supplementarily capable of generating the funds at minor cost when desired by dropping their dividend payments. This study also revealed the positive and significant relationship between cash holding and leverage. It also means that firms want to grab the new opportunities and firms don't have the internal sources, so that's why they are going to take the debt according to the trade-off theory, whereas, some researchers report the contradictory results between them (Al-Najjar \& Belghitar, 2011; Han \& Qiu, 2007; Opler et al., 1999; A. Ozkan \& N. Ozkan, 2004).

\section{Ownership Shareholding Pattern}

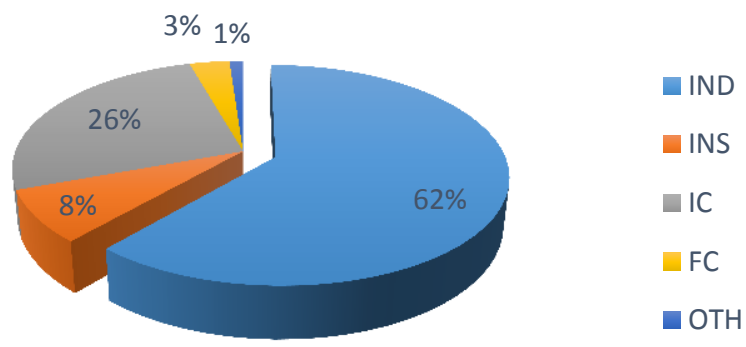

Figure 2. Ownership shareholding pattern

Figure 2 shows the pattern of shareholding of Pakistani firms. The results indicated the part of each shareholding, which are $62 \%$ of individual shareholdings, $8 \%$ of institutional shareholdings, $26 \%$ of investment companies' 
shareholdings and $3 \%$ of foreign shareholdings. According to the above figure, a more significant part of the shareholding pattern belongs to the individual shareholdings and investment companies' shareholdings. It means that Pakistani firms lack foreign shareholding and institutional shareholding, which may cause a greater impact on the firms' corporate governance.

By considering Figure 2 and Table 2 results, the core result of this study reported the inverse relationship between cash holding and individual pattern of shareholding. Although the coefficient of IND relation is not so strong, it clearly stated that Pakistani's firms hold less cash or maintain only necessary cash reserves to meet their operational activities. It also indicated that when an individual pattern of shareholding increases, then cash holding decreases and firms moves outward for financing as this study reveals the results of leverage. Rest, during the financial distress period they get the cash out from their diverted business line, or they generate the money from their source, and this study reported the same as agency theory stated (Cai, Zeng, Lee, \& Ozkan, 2016). Table 2 also indicates the inverse relationship between institutional shareholding and cash holding, which means that cash holding decreases with the increase in the institutional pattern of shareholding. According to A. Ozkan and N. Ozkan (2004) when institutional ownership merges with any organization, then the monitoring policies have changed, and they like to invest more rather than retain the cash safely in their accounts, so that's why it always has a negative relation with cash holding. This model also reported the negative relationship between cash holding and investment company's shareholding, which means the same as an individual shareholding pattern when the pattern of shareholding of investment companies increases then cash holding decreases. Agency theory also reported that when investment companies take part in any company, then they only think about their interest. So that's why it has a negative relation to cash holding. It also indicated that firms pay attention to their shareholders and shareholder wealth. Table 2 also explained the inverse relationship between foreign patterns of shareholding and cash holding. It means when foreign shareholding increases cash holding decreases. Foreign companies or shareholding prefer to cash dividend rather than capital gain, so that's why their companies pay more cash as a dividend to their shareholders that are why cash holding and foreign company's shareholding has an inverse relation.

This study reports the value of the Adjusted $\mathrm{R}$ square is 0.762753 , which means that all the independent variables explain $76 \%$ of the variation in the holding of cash. Table 2 also shows the F-value and P-value, which are 19.25180 and 0.0000 . As the probability value is less than 0.05 which means that firm size, net working capital, market to book asset ratio, liquidity ratio, free cash flow, dividend payout ratio, leverage, individual pattern of shareholding, institutional pattern of shareholding, investment companies shareholding and foreign companies shareholding have sufficiently described the cash holding. It also explains the correctness and consistency of the independent variables to predict the dependent variable and model is the best fit.

\section{Conclusion}

Even though considerable care has paid to the question of the impact of the hierarchy of ownership structure on cash holding? This study cuts down the authority of ownership in-between four different segments according to the consolidated annual reports of firms. This survey is carried on to seek the bulge understanding of why and how ownership structure influences the degree of cash retention, primarily when it carried on a developing country.

As a result, shows the inverse and substantial relationship between cash holding and hierarchy of ownership structure. Individual shareholding, Institutional Shareholding, Investment Companies, and Foreign shareholding all are having a negative and significant relationship with cash holding. In Pakistan, $62 \%$ of shareholding belongs to the individual shareholdings and there is very less part of foreign and institutional shareholding, which may cause poor corporate governance due to the less monitoring of the firm. The main drawback of the developing country is the lack of foreign investment.

This study indeed reveals that the holding of cash depends on the pattern of shareholding with respect to corporate governance. This study proposes that the model of shareholding makes corporate governance stronger or weaker. A balanced number of patterns-shareholding makes corporate governance stronger. Results also report the fact about Pakistani firms that they have a large number of Individual shareholdings rather than institutional and foreign shareholdings, which lead them towards the family shareholding ownership. So, that's why they invariably prefer to invest the money in the line of work instead hold cash. Pakistani firms usually family-oriented firms so they can quickly generate the fund from internal sources or getting loans from their own family and increase their pattern of shareholding. On the other hand, the firms who have not such type of support they maintain the optimal degree of cash reserve to carry through their rainy days and this phenomenon also support the tradeoff theory. This study also concluded that there is no trend in Pakistan to give dividends to their shareholders; they always prefer to re-invest in the business. So that's why the result of this study also shows the insignificant relationship between the cash holding 
and dividend payout ratio.

\subsection{Implications and Future Directions}

This study makes a span for the businessmen in Pakistan to see the real picture of the cash holding phenomena. This study will also help them to manage their cash while knowing the size of the firm and the availability of the funds to grab the opportunities. This study will also help in the line of academia and also contribute to recent literature. Rest, furthermore, this study should be addressed in the context of the political environment while having the entrance of the new government and their policies.

\section{References}

Abor, J. (2005). The effect of capital structure on profitability: an empirical analysis of listed firms in Ghana. The Journal of Risk Finance, 6(5), 438-445. https://doi.org/10.1108/15265940510633505

Abushammala, S. N., \& Sulaiman, J. (2014). Cash holdings and corporate profitability: Some evidences form Jordan. International Journal of Innovation and Applied Studies, 8(3), 898.

Akhtar, T. (2018). Corporate governance and cash holdings: the way forward. Qualitative Research in Financial Markets, 10(2), 152-170. https://doi.org/10.1108/QRFM-04-2017-0034

Al-Najjar, B. (2013). The financial determinants of corporate cash holdings: Evidence from some emerging markets. International Business Review, 22(1), 77-88. https://doi.org/10.1016/j.ibusrev.2012.02.004

Al-Najjar, B., \& Belghitar, Y. (2011). Corporate cash holdings and dividend payments: evidence from simultaneous analysis. Managerial and Decision Economics, 32(4), 231-241. https://doi.org/10.1002/mde.1529

Al-Najjar, B., \& Clark, E. (2017). Corporate governance and cash holdings in MENA: Evidence from internal and external governance practices. Research in International Business and Finance, 39, 1-12. https://doi.org/10.1016/j.ribaf.2016.07.030

Anake Atseye, F., Ugwu, J., \& Takon, S. (2015). Determinants of Working Capital Management Theoretical Review (Vol. III).

Bates, T. W., Kahle, K. M., \& Stulz, R. M. (2009). Why do US firms hold so much more cash than they used to?. The Journal of Finance, 64(5), 1985-2021. https://doi.org/10.1111/j.1540-6261.2009.01492.x

Bayoumi, T., Tong, H., \& Wei, S.-J. (2012). The Chinese corporate savings puzzle: a firm-level cross-country perspective. Capitalizing China (pp. 283-308). University of Chicago Press. https://doi.org/10.2139/ssrn.2138718

Bigelli, M., \& Sánchez-Vidal, J. (2012). Cash holdings in private firms. Journal of Banking \& Finance, 36(1), 26-35. https://doi.org/10.1016/j.jbankfin.2011.06.004

Cai, W., Zeng, C., Lee, E., \& Ozkan, N. (2016). Do business groups affect corporate cash holdings? Evidence from a transition economy. China Journal of Accounting Research, 9(1), 1-24. https://doi.org/10.1016/j.cjar.2015.10.002

Campbell, T., \& Brendsel, L. (1977). The Impact of Compensating Balance Requirements on the Cash Balances of Manufacturing Corporations: An Empirical Study. The Journal of Finance, 32(1), 31-40. https://doi.org/10.2307/2326900

Chen, Y. R. (2008). Corporate governance and cash holdings: Listed new economy versus old economy firms. Corporate Governance: An International Review, 16(5), 430-442. https://doi.org/10.1111/j.1467-8683.2008.00701.x

Claessens, S., Djankov, S., \& Lang, L. H. P. (2000). The separation of ownership and control in East Asian Corporations. Journal of Financial Economics, 58(1), 81-112. https://doi.org/10.1016/S0304-405X(00)00067-2

Coase, R. H. (1937). The nature of the firm. Economica, 4(16), 386-405. https://doi.org/10.1111/j.1468-0335.1937.tb00002.x

Dang, C., Li, Z. F., \& Yang, C. (2018). Measuring firm size in empirical corporate finance. Journal of Banking \& Finance, 86, 159-176. https://doi.org/10.1016/j.jbankfin.2017.09.006

Dittmar, A., \& Mahrt-Smith, J. (2007). Corporate governance and the value of cash holdings. Journal of Financial Economics, 83(3), 599-634. https://doi.org/10.1016/j.jfineco.2005.12.006

Dittmar, A., Mahrt-Smith, J., \& Servaes, H. (2003). International corporate governance and corporate cash holdings. 
Journal of Financial and Quantitative Analysis, 38(1), 111-133. https://doi.org/10.2307/4126766

Drobetz, W., \& Grüninger, M. C. (2007). Corporate cash holdings: Evidence from Switzerland. Financial Markets and Portfolio Management, 2l(3), 293-324. https://doi.org/10.1007/s11408-007-0052-8

Faulkender, M., \& Wang, R. (2006). Corporate Financial Policy and the Value of Cash (Vol. 61). https://doi.org/10.1111/j.1540-6261.2006.00894.x

Ferreira, M. A., \& Vilela, A. S. (2004). Why do firms hold cash? Evidence from EMU countries. European Financial Management, 10(2), 295-319. https://doi.org/10.1111/j.1354-7798.2004.00251.x

Gao, H., Harford, J., \& Li, K. (2013). Determinants of corporate cash policy: Insights from private firms. Journal of Financial Economics, 109(3), 623-639. https://doi.org/10.1016/j.jineco.2013.04.008

García-Teruel, P. J., \& Martínez-Solano, P. (2008). On the determinants of SME cash holdings: Evidence from Spain. Journal of Business Finance \& Accounting, 35(1-2), 127-149. https://doi.org/10.1111/j.1468-5957.2007.02022.x

Giroud, X., \& Mueller, H. M. (2011). Corporate Governance, Product Market Competition, and Equity Prices. The Journal of Finance, 66(2), 563-600. https://doi.org/10.1111/j.1540-6261.2010.01642.x

Grossman, S. J., \& Hart, O. D. (1986). The costs and benefits of ownership: A theory of vertical and lateral integration. Journal of Political Economy, 94(4), 691-719. https://doi.org/10.1086/261404

Guizani, M. (2017). The financial determinants of corporate cash holdings in an oil rich country: Evidence from Kingdom of Saudi Arabia. Borsa Istanbul Review, 17(3), 133-143. https://doi.org/10.1016/j.bir.2017.05.003

Guney, Y., Ozkan, A., \& Ozkan, N. (2007). International evidence on the non-linear impact of leverage on corporate cash holdings. Journal of Multinational Financial Management, 17(1), 45-60. https://doi.org/10.1016/j.mulfin.2006.03.003

Han, S., \& Qiu, J. (2007). Corporate Precautionary Cash Holdings (Vol. 13). https://doi.org/10.1016/j.jcorpfin.2006.05.002

Harford, J. (1999). Corporate Cash Reserves and Acquisitions. The Journal of Finance, 54(6), 1969-1997. https://doi.org/10.1111/0022-1082.00179

Harford, J., Mansi, S. A., \& Maxwell, W. F. (2008). Corporate governance and firm cash holdings in the US. Journal of Financial Economics, 87(3), 535-555. https://doi.org/10.1016/j.jfineco.2007.04.002

Horioka, C. Y., \& Terada-Hagiwara, A. (2013). Corporate cash holding in Asia. https://doi.org/10.3386/w19688

Jensen, M. C. (1986). Agency Costs of Free Cash Flow, Corporate Finance, and Takeovers. The American Economic Review, 76(2), 323-329.

Jensen, M. C., \& Meckling, W. H. (1976). Theory of the firm: Managerial behavior, agency costs and ownership structure. Journal of Financial Economics, 3(4), 305-360. https://doi.org/10.1016/0304-405X(76)90026-X

Kim, C.-S., Mauer, D. C., \& Sherman, A. E. (1998). The determinants of corporate liquidity: Theory and evidence. Journal of Financial and Quantitative Analysis, 33(3), 335-359. https://doi.org/10.2307/2331099

Klein, B., Crawford, R. G., \& Alchian, A. A. (1978). Vertical integration, appropriable rents, and the competitive contracting process. The Journal of Law and Economics, 21(2), 297-326. https://doi.org/10.1086/466922

Myers, S. C. (1977). Determinants of corporate borrowing. Journal of Financial Economics, 5(2), 147-175. https://doi.org/10.1016/0304-405X(77)90015-0

Myers, S. C., \& Majluf, N. S. (1984). Corporate financing and investment decisions when firms have information that investors do not have. Journal of Financial Economics, 13(2), 187-221. https://doi.org/10.1016/0304-405X(84)90023-0

Nadiri, M. I. (1969). The Determinants of Real Cash Balances in the U.S. Total Manufacturing Sector*. The Quarterly Journal of Economics, 83(2), 173-196. https://doi.org/10.2307/1883079

Ng, C. Y. M. (2005). An Empirical Study on the Relationship between Ownership and Performance in a Family-Based Corporate Environment. Journal of Accounting, Auditing \& Finance, 20(2), 121-146. https://doi.org/10.1177/0148558X0502000202

Opler, T., Pinkowitz, L., Stulz, R., \& Williamson, R. (1999). The determinants and implications of corporate cash holdings. Journal of Financial Economics, 52(1), 3-46. 
Ozkan, A., \& Ozkan, N. (2004). Corporate cash holdings: an empirical investigation of UK companies. Journal of Banking and Finance, 28(9), 2103-2134. https://doi.org/10.1016/j.jbankfin.2003.08.003

Rajan, R. G., \& Zingales, L. (1995). What do we know about capital structure? Some evidence from international data. The Journal of Finance, 50(5), 1421-1460. https://doi.org/10.1111/j.1540-6261.1995.tb05184.x

Ranajee, R., \& Pathak, R. (2019). Corporate cash holding during crisis and beyond: what matters the most. International Journal of Managerial Finance.

Rizwan, M. F., \& Javed, T. (2011). Determinants of corporate cash holdings: Evidence from pakistani corporate sector. Economics, Management and Financial Markets, 6(1), 344.

Saddour, K. (2006). The determinants and the value of cash holdings: Evidence from French firms.

Singh, H. P., \& Kumar, S. (2017). Working capital requirements of manufacturing SMEs: evidence from emerging economy. Review of International Business and Strategy, 27(3), 369-385. https://doi.org/10.1108/RIBS-03-2017-0027

Smith Jr., C. W., \& Warner, J. B. (1979). On financial contracting: An analysis of bond covenants. Journal of Financial Economics, 7(2), 117-161. https://doi.org/10.1016/0304-405X(79)90011-4

Stulz, R. (1990). Managerial discretion and optimal financing policies. Journal of Financial Economics, 26(1), 3-27. https://doi.org/10.1016/0304-405x(90)90011-n

Sun, J., Ding, L., Guo, J. M., \& Li, Y. (2016). Ownership, capital structure and financing decision: Evidence from the UK. The British Accounting Review, 48(4), 448-463. https://doi.org/10.1016/j.bar.2015.04.001

Tayem, G. (2017). The Determinants of Corporate Cash Holdings: The Case of a Small Emerging Market. International Journal of Financial Research, 8(1), 143-154. https://doi.org/10.5430/ijfr.v8n1p143

Titman, S., \& Wessels, R. (1988). The determinants of capital structure choice. The Journal of Finance, 43(1), 1-19. https://doi.org/10.1111/j.1540-6261.1988.tb02585.x

Wali Ullah, G. M., Zahid, A., Khan, I., \& Islam, N. (2018). Working Capital Management and SME Profitability: Empirical Evidence from Bangladesh (Vol. 5).

Weidemann, J. F. (2018). A state-of-the-art review of corporate cash holding research. Journal of Business Economics, 88(6), 765-797. https://doi.org/10.1007/s11573-017-0882-4

Williamson O. E. (1993). Calculativeness, trust and economic organization. Journal of Law and Economics, 36, 453-486. https://doi.org/10.1086/467284

Williamson, O. (1985). The Economic Institutions of Capitalism. The Free Press New York.

Williamson, O. E. (1975). Markets and hierarchies. New York. 